\title{
Seasonal changes in lung function in a farming population
}

\author{
Ambikaipakan Senthilselvan $\mathrm{PhD}^{1,2}$, James A Dosman $\mathrm{MD}^{1}$, Karen M Semchuk $\mathrm{PhD}^{3}$, \\ Helen H McDuffie $P h D^{1}$, Allan J Cessna $\mathrm{PhD}^{4}$, Donald G Irvine $\mathrm{PhD}^{5}$, \\ Margaret FO Crossley $\mathrm{PhD}^{6}$, Alan Rosenberg $\mathrm{MD}^{7}$ \\ ${ }^{1}$ Centre for Agricultural Medicine, ${ }^{2}$ Department of Community Health and Epidemiology, and \\ ${ }^{3}$ College of Nursing, University of Saskatchewan, Saskatoon, Saskatchewan; ${ }^{4}$ Agriculture \& \\ Agri-Food Canada, Research Centre, Lethbridge, Alberta; ${ }^{5}$ Toxicology Group, ${ }^{6}$ Department of \\ Psychology and ${ }^{7}$ Department of Pediatrics, University of Saskatchewan, Saskatoon, \\ Saskatchewan
}

\begin{abstract}
A Senthilselvan, JA Dosman, KM Semchuk, et al. Seasonal changes in lung function in a farming population. Can Respir J 2000;7(4):320-325.
\end{abstract}

OBJECTIVE: To assess the changes in respiratory health from winter to summer seasons in a rural population.

DESIGN: A longitudinal design was used in the study.

SETTING: A population-based study was conducted as part of the Environmental Pesticide Exposure and Human Health component of the Prairie Ecosystem Study (PECOS) in southwestern Saskatchewan.

PATIENTS: In the winter season, 358 patients participated in the study. Of these patients, 234 returned for the second assessment during the summer season. After excluding 34 children aged 17 years and under, 200 adult patients were available for analysis.

MEASUREMENTS: Questionnaires were used to obtain information on demographic factors, smoking habits, occupational and environmental exposures, and respiratory conditions. Pulmonary function measurements were obtained using a volume displacement spirometer.

RESULTS: Mean ages $( \pm$ SD) of the 106 men and 94 women participating in the study were $50.1 \pm 13.3$ and $49.0 \pm 13.1$ years, respectively. Mean percentage changes in maximal midexpiratory flow rate from winter to summer assessments indicated an improvement for town residents and a decline for farm residents. Mean percentage changes in the ratio of forced expiratory volume in $1 \mathrm{~s}$ to forced vital capacity indi- cated an improvement for town residents who were not engaged in farming, and increasing declines for town residents engaged in farming, farm residents not engaged in farming and farm residents engaged in farming.

CONCLUSIONS: Seasonal changes occurred in measurements of pulmonary function between winter and summer seasons; these changes may be related to the environmental or occupational exposures experienced by the participants during the study.

Key Words: Grain farming; Lung function; Pesticides; Rural population; Seasonal changes

Incidence du changement de saison sur le fonctionnement respiratoire chez des agriculteurs

OBJECTIF : Évaluer les changements de santé pulmonaire durant l'hiver et l'été dans une population rurale

TYPE D'ÉTUDE : Étude longitudinale

MILIEU : Une étude dans la population générale a été menée, dans le sud-ouest de la Saskatchewan, dans le cadre du volet Environmental Pesticide Exposure and Human Health de l'étude Prairie Ecosystem Study (PECOS).

PATIENTS : Au cours de l'hiver, 358 sujets ont participé à l'étude; de ce nombre, 234 se sont présentés de nouveau pour la deuxième évaluation faite au cours de l'été. Après l'exclusion de 34 enfants âgés de 17 ans ou moins, il est resté 200 sujets adultes pour l'étude. MESURES : Les renseignements sur les facteurs démographiques, le tabagisme, l'exposition professionnelle ou environnementale à diverses substances et les troubles respiratoires ont été obtenus au

voir page suivante

Correspondence and reprints: Dr A Senthilselvan, 13-106D Clinical Sciences Building, Department of Public Health Sciences, University of Alberta, Edmonton, Alberta T6G 2G3. Telephone 780-492-6505, fax 780-492-0364, e-mail sentil@ ualberta.ca 
moyen de questionnaires. Quant à l'exploration du fonctionnement respiratoire, on s'est servi d'un spiromètre pour mesurer les volumes gazeux mobilisés.

RÉSULTATS : L'âge moyen (écart type) des 106 hommes et des

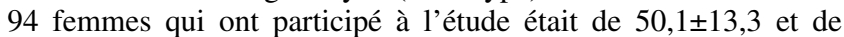
$49,0 \pm 13,1$ respectivement. Les écarts de pourcentage moyen enregistrés dans le débit maximal expiratoire médian au moment des évaluations faites en hiver et en été révèlent une amélioration du fonctionnement respiratoire dans la population urbaine et une détérioration de celui-ci dans la population rurale. Quant au rapport du volume expiratoire maximum-seconde sur la capacité vitale, les écarts de pourcentage moyen font état d'une amélioration pour les habitants de la ville ne s'adonnant pas à l'agriculture et d'une détérioration croissante chez les habitants de la ville s'adonnant à l'agriculture, les habitants de la campagne ne s'adonnant pas à l'agriculture et les agriculteurs eux-mêmes.

CONCLUSION : Des écarts ont été enregistrés dans les mesures du fonctionnement respiratoire, prises durant l'hiver et l'été; ces écarts peuvent être liés à l'exposition professionnelle ou environnementale des participants à diverses substances durant l'étude.
$\mathrm{F}$ arm dwellers are occupationally exposed to dusts, chemicals and allergens. Increased prevalence of respiratory symptoms and decreased lung function values have been reported in epidemiological studies of grain farmers (1-4). Exposure to grain farming is associated with an increased prevalence of asthma and chronic bronchitis $(5,6)$. In a longitudinal study, the annual rate changes in forced expiratory volume in $1 \mathrm{~s}\left(\mathrm{FEV}_{1}\right)$ and forced vital capacity (FVC) were significantly greater among grain farmers than among nonfarming rural dwelling subjects (7). Several studies have investigated acute changes in respiratory health during elevated dust exposure in grain farmers $(3,8,9)$.

In the present study, the determinants of changes in pulmonary function from winter (February and March 1996) to summer (June and July 1996) seasons in a rural population in southwestern Saskatchewan were examined. During the winter season in this part of Saskatchewan, the soil is frozen and is usually covered with snow, and with the exception of hauling grain for sale at grain elevators, there is little farming activity with respect to grain production. However, between the winter and summer seasons as defined in this study, farmers can be involved in several activities. During the snow melt in late winter and spring, farmers generally make repairs to machinery and equipment, and may be involved in seed cleaning operations and treating seed with fungicides for disease control. Seeding usually occurs in May, after the snow melt between late March and late April. Depending on the tillage system used, seeding may be preceded by cultivation and/or harrowing operations, as well as by the application of fertilizer and pre-emergence soilincorporated herbicides. Fertilizer can also be applied simultaneously during seeding. The spraying of postemergence herbicides is the main activity during the summer season. Insecticides are also applied to control the spread of grasshoppers, Bertha army worms, wheat midge and other insects as infestations occur. The majority of herbicides and insecticides are applied by farmers using tractor-pulled sprayers.

\section{PATIENTS AND METHODS}

Six administrative regions comprised of three rural municipalities and three towns were chosen for the study from the Census Agricultural Region 3BN in southwestern Saskatchewan. There were 2128 rural residents and 1408 town residents in the study area (10). Grain production was the main farming operation among the 755 farms located in the study area (11).
In November 1995, a community canvas was conducted to provide a health-related descriptive study of the rural population, and to recruit subjects for assessments in winter and summer seasons. From the local area canvassers, 1185 households and farmsteads accepted an envelope containing a questionnaire for the descriptive study and a reply card for indicating willingness to participate in the two assessments. Of these households, $549(46.3 \%)$ returned the questionnaire and 259 (21.9\%) households returned the reply card. Only some of the households returned both the questionnaire and the reply card. From the 259 households (581 individuals) that returned the reply card, 375 (64.5\%) individuals participated in the winter assessments, which were conducted during February and March 1996. Winter season assessments included pulmonary function tests, respiratory symptom questionnaires, self-administered questionnaires on demography, general health, occupational history and use of pesticides.

In the winter assessment, 358 patients (306 adults and 52 children aged 17 years and under) had pulmonary function tests and completed a brief respiratory symptom questionnaire. Pulmonary function tests were not conducted on 17 individuals who were pregnant, or had high blood pressure, recent chest surgery, abdominal surgery or chest injuries.

Of the 375 individuals who participated in the winter assessment, 254 (67.7\%) returned for the second assessment in June and July 1996. Pulmonary function tests were conducted on 234 individuals $(62.4 \%, 200$ adults and 34 children aged 17 years and under). Because the majority of study participants were adults, 34 children were excluded from the study. In the present article, the results from 200 adults who had pulmonary function measurements at winter and summer assessments are presented. The period of second assessment will be referred to as the 'summer season'.

'Current occupation' was defined using multiple responses to the question "What is your current occupation?". If the response of study participants included crop farming (grain, oilseeds or pulses) and farm labour, their current occupation was defined as 'farming'. The response to the question "Where do you live most of the year (Farm/Town)?" was used to define the current residence of study participants. The information on current farming and current residence was combined to define four mutually exclusive study groups: town nonfarmers, town farmers, farm resident nonfarmers and farm resident farmers.

Lung function test measurements were made according to 
TABLE 1

Comparison of participants in winter and summer assessments with dropouts from summer assessment in a rural population in southwestern Saskatchewan

\begin{tabular}{|c|c|c|c|}
\hline & $\begin{array}{l}\text { Participants in winter and summer assessments } \\
\qquad(\mathrm{n}=200)\end{array}$ & $\begin{array}{l}\text { Participants in winter assessment only } \\
\qquad(n=106)\end{array}$ & $\mathbf{P}$ \\
\hline & Mean \pm SD & Mean \pm SD & \\
\hline Age (years) & $49.6 \pm 13.2$ & $50.3 \pm 13.1$ & 0.62 \\
\hline Weight (kg) & $79.6 \pm 15.8$ & $82.4 \pm 20.4$ & 0.23 \\
\hline $\mathrm{FEV}_{1}(\mathrm{~L})$ & $3.36 \pm 0.86$ & $3.25 \pm 0.82$ & 0.24 \\
\hline \multirow[t]{2}{*}{$\mathrm{FEV}_{1}$ to $\mathrm{FVC}$ ratio $(\%)$} & $75.5 \pm 6.80$ & $75.9 \pm 8.83$ & 0.68 \\
\hline & Number $(\%)$ & Number (\%) & \\
\hline \multicolumn{4}{|l|}{ Sex } \\
\hline Male & $106(53.0)$ & $56(52.8)$ & 0.98 \\
\hline Smoker & $17(8.7)$ & $18(18.2)$ & \\
\hline Missing & 5 & 7 & \\
\hline \multicolumn{4}{|l|}{ Study groups } \\
\hline Town nonfarmers & $39(20.2)$ & $22(22.7)$ & 0.91 \\
\hline Town farmers & $17(8.8)$ & $10(10.3)$ & \\
\hline Resident nonfarmers & $32(16.6)$ & $16(16.5)$ & \\
\hline Resident farmers & $105(54.4)$ & $49(50.5)$ & \\
\hline Missing & 7 & 9 & \\
\hline
\end{tabular}

FEV 1 Forced expiratory volume in $1 \mathrm{~s} ;$ FVC Forced vital capacity; MMFR Maximal midexpiratory flow rate

American Thoracic Society specifications (12) using a SensorMedics volume displacement spirometer (SensorMedics, United States) in winter and summer assessments. The pulmonary function test variables $-\mathrm{FVC}, \mathrm{FEV}_{1}, \mathrm{FEV}_{1}$ to $\mathrm{FVC}$ ratio $\left(\mathrm{FEV}_{1}: \mathrm{FVC}\right)$ and maximal midexpiratory flow rate (MMFR) - were measured. The three experienced technicians who conducted pulmonary function measurements participated in training sessions before the field testing, and were blinded to the participants' farming and residential status. The change in pulmonary function was calculated by dividing the change between winter and summer measurements by the winter measurement, and was expressed as a percentage.

Statistical analysis: Means and standard errors or standard deviations were used to describe the distribution of continuous variables. Categorical variables were described by frequencies and percentages. Analysis of covariance was used to test differences in the percentage change in pulmonary function from winter to summer seasons after adjusting for age, height and sex. Multivariate regression analysis was used to test the difference in the changes in lung function among the four study groups after controlling for potential confounding variables such as age, sex, height and smoking.

\section{RESULTS}

As shown in Table 1, no statistically significant differences were observed in comparisons of age, sex, height, weight, residence or pulmonary function test variables be- tween the participants in both winter and summer assessments, and the dropouts from the summer assessment. The percentage of current smokers in the dropout group was significantly higher than in the participant group.

The characteristics of the four study groups are shown in Table 2. Farm residents were significantly younger than the town residents. Farmers who lived both in town and on the farm were taller and heavier than nonfarmers. No significant differences were observed in the time interval between the winter and summer assessments. More male than female patients were engaged in farming among town and farm residents.

In Figure 1, percentage changes in pulmonary function from winter to summer assessments are illustrated for the four study groups. Significant trends were observed among the four study groups in MMFR and $\mathrm{FEV}_{1}$ :FVC after adjusting for age, height and sex. Mean percentage changes in MMFR from winter to summer assessments indicated an improvement for town residents and a decline for farm residents. Mean percentage changes in $\mathrm{FEV}_{1}: \mathrm{FVC}$ from winter to summer assessments indicated an improvement for town residents who were not engaged in farming, and increasing declines for town residents engaged in farming, farm residents not engaged in farming and farm residents engaged in farming.

Multiple regression analyses were used to examine differences between farm and town dwellers in the percentage 
TABLE 2

Characteristics of study groups in a rural population in southwestern Saskatchewan

\begin{tabular}{|c|c|c|c|c|c|}
\hline & $\begin{array}{l}\text { Town resident nonfarmers } \\
(\mathrm{n}=39)\end{array}$ & $\begin{array}{c}\text { Town resident farmers } \\
(\mathrm{n}=17)\end{array}$ & $\begin{array}{l}\text { Farm resident nonfarmers } \\
\qquad(\mathrm{n}=32)\end{array}$ & $\begin{array}{l}\text { Farm resident farmers } \\
\qquad(n=105)\end{array}$ & $\mathbf{P}$ \\
\hline & Mean \pm SD & Mean \pm SD & Mean \pm SD & Mean \pm SD & \\
\hline Age (years) & $52.5 \pm 16.1$ & $56.7 \pm 16.3$ & $47.4 \pm 14.1$ & $48.4 \pm 10.4$ & 0.03 \\
\hline Weight (kg) & $76.6 \pm 15.8$ & $79.7 \pm 16.8$ & $70.1 \pm 13.0$ & $83.9 \pm 15.4$ & $<0.001$ \\
\hline $\begin{array}{l}\text { Time period } \\
\text { (days) }^{\star}\end{array}$ & $113.5 \pm 13.1$ & $108.3 \pm 13.3$ & $110.4 \pm 11.8$ & $110.9 \pm 11.8$ & 0.48 \\
\hline \multicolumn{6}{|l|}{ Sex } \\
\hline Males & $15(38.5)$ & $12(70.6)$ & $3(9.4)$ & $71(67.6)$ & $<0.001$ \\
\hline Females & $24(61.5)$ & $5(29.4)$ & $29(90.6)$ & $34(32.4)$ & \\
\hline \multicolumn{6}{|c|}{ Smoking status } \\
\hline Nonsmoker & $22(56.4)$ & $7(57.8)$ & $17(53.1)$ & 61 (59.2) & 0.26 \\
\hline
\end{tabular}

*Exact time interval between individuals' winter and summer assessments

changes in MMFR and $\mathrm{FEV}_{1}$ :FVC after adjusting for age, sex, height and smoking status (Table 3 ). As indicated by the significance levels of the regression coefficients for the study group variables in Table 3, percentage declines in MMFR and $\mathrm{FEV}_{1}$ :FVC were significantly different between town nonfarmer and farm resident farmer groups. In addition, significant differences were observed in $\mathrm{FEV}_{1}$ :FVC between town nonfarmer and farm resident farmer groups.

The relationship between seasonal changes in pulmonary function and use of pesticides during the study period was examined among patients who reported that their main occupation was farming. Of the 200 study participants, 125 reported that they were currently engaged in farming; among those, use of any pesticide was reported by $105(84.0 \%)$ (herbicide use 82 [65.6\%]; insecticide use 52 [41.6\%]; fungicide use 59 [47.2\%]; and algicide or adjuvant use seven [5.6\%]). No significant difference was observed in the percentage change in pulmonary function between users and nonusers of pesticides, or in any of the pesticide subcategories.

Histograms and normal plots of the percentage changes in MMFR and $\mathrm{FEV}_{1}: \mathrm{FVC}$ were obtained to assess the normality of these variables. There were no extreme outliers in the percentage changes in MMFR, whereas two observations had $15 \%$ or greater declines in $\mathrm{FEV}_{1}: \mathrm{FVC}$. To assess the influence of these observations, regression analysis was conducted after removing these observations. In the regression analysis, statistical significance of farm variables changed slightly, but overall conclusions did not change. Therefore, the observations were included in the regression analysis described in Table 3.

A variable indicating the presence or absence of asthma was included in the regression to assess the importance of asthma in predicting the percentage changes in MMFR and $\mathrm{FEV}_{1}: \mathrm{FVC}$. These variables were not statistically significant in the regression analysis and were not included in the final model described in Table 3.

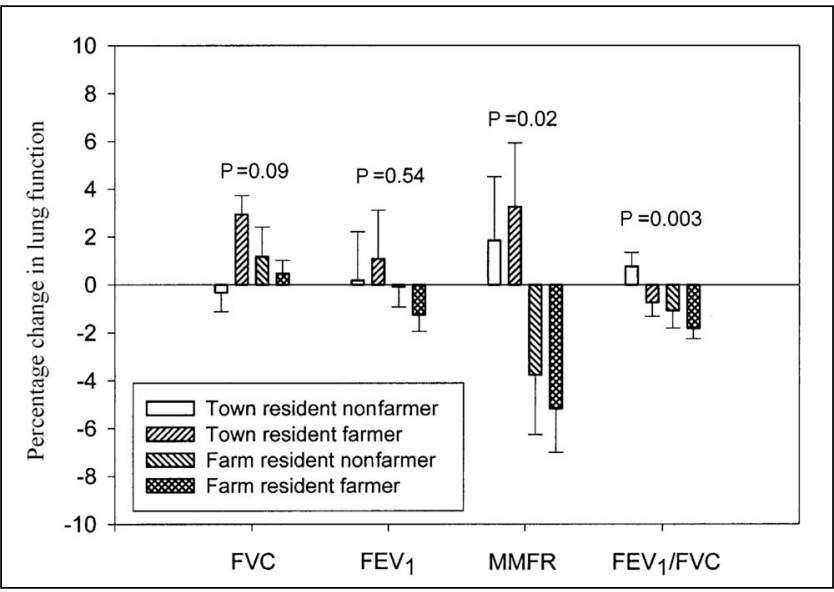

Figure 1) Percentage changes in pulmonary function from winter to summer seasons for participants in a rural population study in southwestern Saskatchewan. Error bars indicate one standard error. $P$ values indicate the significance in the trend across the four study groups after controlling for age, sex and height. FEV $V_{l}$ Forced expiratory volume in $1 \mathrm{~s}$; FVC Forced vital capacity; MMFR Maximal midexpiratory flow rate

\section{DISCUSSION}

In the present study, subjects who lived on a farm and engaged in farming had the highest mean declines in MMFR and $\mathrm{FEV}_{1}: \mathrm{FVC}$ from winter to summer seasons, whereas subjects who lived in town and were not engaged in farming had improvements in MMFR and $\mathrm{FEV}_{1}: \mathrm{FVC}$. Regardless of whether they were engaged in farming, farm residents had declines in both MMFR and $\mathrm{FEV}_{1}: \mathrm{FVC}$. Town residents engaged in farming had a decline in $\mathrm{FEV}_{1}: \mathrm{FVC}$ and an improvement in MMFR.

The most common farming operations among study participants were grain farming and oil seed production. Other farming operations included beef cattle, hog and poultry farming. Farmers and their family members residing on the 
TABLE 3

Relationship between the percentage changes in pulmonary function and study groups after adjusting for potential confounders by multiple regression analyses

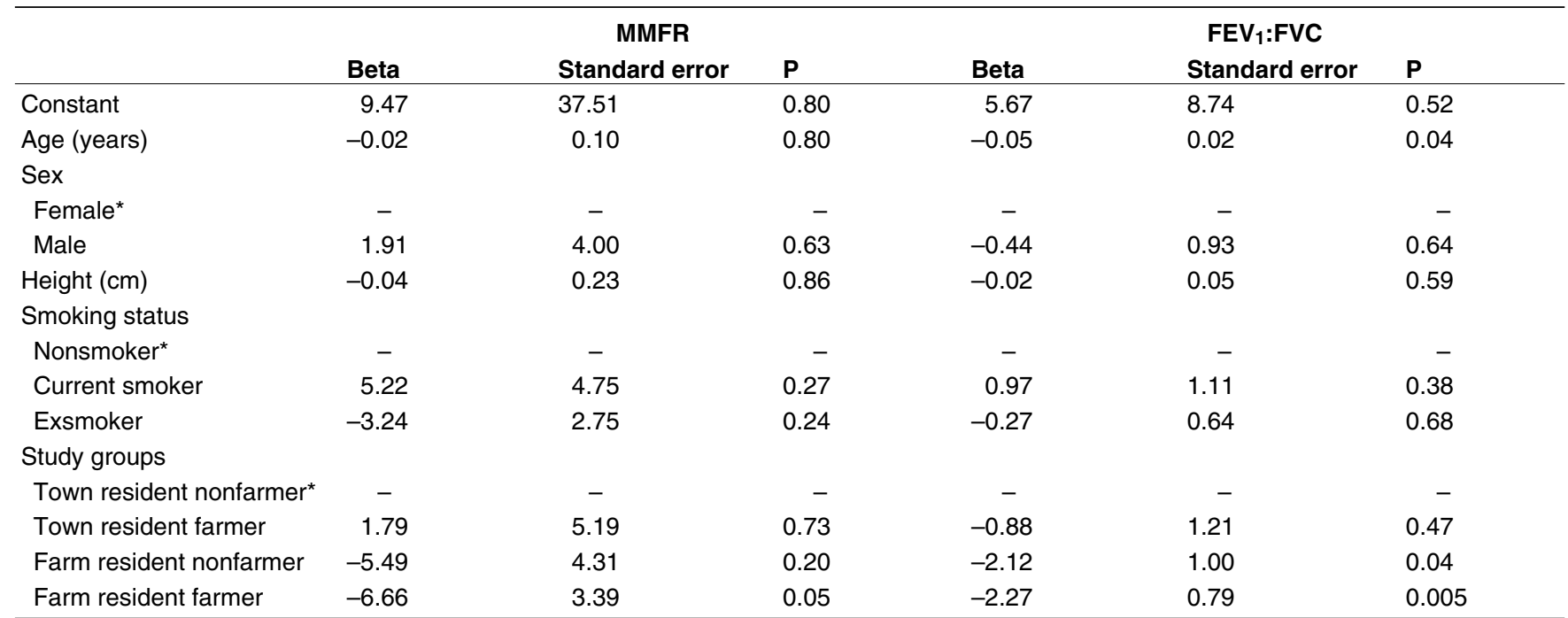

${ }^{*}$ Comparison group. FEV 1 : FVC Forced expiratory volume in $1 \mathrm{~s}$ to forced vital capacity ratio; MMFR Maximal midexpiratory flow rate

farm are likely to be exposed to multiple environmental and occupational agents, such as grain dust, grain dust mites, pollen, fungal spores, animal products, insecticides, herbicides, fungicides, fertilizers, fumigants and gases from plant decomposition (13). The respiratory diseases associated with inhaling these substances include asthma, bronchitis, chronic airway obstruction and hypersensitivity pneumonitis $(5,6,14,15)$. Interpretation of data from the present study is obviously hampered by the lack of direct measurements of environmental and occupational exposure.

In the present study, farm dwellers had a significantly greater decline in $\mathrm{FEV}_{1}$ :FVC and MMFR from winter to summer seasons compared with the nonfarm dwellers. This pattern was observed in both men and women, but the decline was significantly different only in the men. In a study conducted in Australia to determine changes in respiratory health in seasonal grain farm workers during peak farming activities, James and coworkers (3) studied 119 young men before grain harvest and towards the end of harvest after a mean work period of 18 days. They found that those reporting respiratory symptoms at work had a significantly greater decline in $\mathrm{FEV}_{1}$ than those who did not report any respiratory symptoms. In contrast, a study by Manfreda et al (9) of 76 grain farmers before, during and after harvest, and during a working day, showed no significant changes in peak expiratory flow rates taken during different levels of farming activities.

Pulmonary function measurements depend on several factors such as testing equipment, test performance, quality control and technician training (12). In the present study, the same equipment was used for both winter and summer pulmonary function assessments, and the technicians were not aware of the research objectives of the study. In a population-based study to examine the effect of learning on repeated pulmonary function tests, 112 patients participated in pulmonary function testing twice within an interval of 0.5 to six months (17). In the present study, the intra-individual differences between the two pulmonary function tests were small and not significantly related to the subjects' age, sex, height, weight, social status or motivation, whether the same or a different technician conducted the two tests, or duration of the time interval between the two tests. In our study, intra-individual variation in MMFR and $\mathrm{FEV}_{1}: \mathrm{FVC}$ over a three- to four-month period was statistically significant among farm dwellers but not among nonfarm dwellers (Figure 1). These results raise the possibility that factors (eg, grain dust, grain dust mites, pollen, fungal spores, animal products, pesticides) other than measurement error were responsible for the decline in specific pulmonary function measurements among farm dwellers.

What are the limitations of our study? Only $21.9 \%$ of the eligible households agreed to participate in the first assessment, and only 250 (66.7\%) of the 375 subjects who did participate in the baseline assessment returned for the second assessment. The participants in the present study represent a self-selected sample, and the results should be interpreted with caution when generalizing to other populations. Our analysis, however, includes only those subjects who participated in both winter and summer assessments. Each subject was his or her own control in our study. Many of the demographic and physiological measurements were similar between those who participated in both of the assessments and those who dropped out from the second assessment, but there was a significant difference in smoking habits between the two groups: $18.2 \%$ of the subjects who dropped out were smokers compared with $8.7 \%$ of those who remained. Because smokers tend to have accelerated lung function decline in comparison with nonsmokers (18), the bias due to the lower response rate of smokers in the second assessment 
would be towards the null hypothesis of no decline in lung function between the two assessments.

In our study, the decline in pulmonary function was significantly greater in farm residents than in town residents. These results raise the possibility that repeated, short term exposures to inhaled substances could cumulatively result in long term reductions in pulmonary function test values in exposed populations. Studies by doPico et al (19) have demonstrated that short term exposures to grain dust results in considerable transient reductions in $\mathrm{FEV}_{1}$, and these findings were recently confirmed in farmers shovelling grain in a storage facility for a relatively short period (approximately $1 \mathrm{~h}$ ) (20). It has been demonstrated that shift changes in workers exposed to biological contaminants in swine confinement facilities are predictive of longitudinal declines in pulmonary function test values over a four-year period $(21,22)$. Also, we have previously demonstrated a relationship between carbamate insecticides and asthma in grain farmers (23), but only seven farmers in this study reported use of carbamate insecticides during the study period. Altogether, it would appear reasonable to speculate that the single-season reductions in lung function test values that were observed in this study could contribute to the kind of long term reductions in mean values that were previously documented in a population of farmers in Saskatchewan (2). Further research is required to identify more precisely the factors associated with changes in lung function among farm residents, to determine causal mechanisms involved and to clarify the degree to which single-season declines relate to long term loss of lung function.

ACKNOWLEDGEMENTS: This research is part of the larger interdisciplinary study of the Sustainability of the Semi-Arid Prairie Ecosystem (PECOS) funded by the Eco-Research Program, Tri-Council Secretariat of Canada. The authors thank the following individuals for their contributions to the study: Ms Donna Ledingham (data management); Ms Leslie Holfeld, Ms Janice Colquhoun and Ms Shelley Kirychuk (pulmonary function measurements); Ms Michele Masley and Ms Louise Hagel (scientific meetings); Victor Juorio (data entry); and Pat Hanke (study design and implementation).

\section{REFERENCES}

1. Heller RF, Hayward DM, Farebrother MTB. Lung function of farmers in England and Wales. Thorax 1986;41:117-21.

2. Dosman JA, Graham BL, Hall D, Van Loon P, Bhasin P, Froh F. Respiratory symptoms and pulmonary function in farmers. J Occup Med 1987;29:38-43.
3. James AL, Cookson WOCM, Buters G, et al. Symptoms and longitudinal changes in lung function in young seasonal grain handlers. Br J Ind Med 1986;43:587-91.

4. Moira CY, Enarson DA, Kennedy SM. The impact of grain dust on respiratory health. Am Rev Respir Dis 1992;145:476-87.

5. Senthilselvan A, Chen Y, Dosman JA. Predictors of asthma and wheezing in adults: Grain farming, sex, and smoking. Am Rev Respir Dis 1993;148:667-70.

6. Chen Y, Horne SL, McDuffie HH, Dosman JA. Combined effect of grain farming and smoking on lung function and the prevalence of chronic bronchitis. Int J Epidemiol 1991;20:416-23.

7. Senthilselvan A, Dosman JA, Kirychuk SP, et al. Accelerated lung function decline in swine confinement workers. Chest 1997;111:1733-41.

8. Darke CS, Knowelden J, Lacey J, Milford-Ward A. Respiratory disease of workers harvesting grain. Thorax 1976;31:294-302.

9. Manfreda J, Holford-Strevens V, Cheang M, Warren CPW. Acute symptoms following exposure to grain dust in farming. Environ Health Perspect 1986;66:73-80.

10. Saskatchewan Covered Populations, 1996. Health insurance registration information system branch. Regina: Saskatchewan Health Department, 1996.

11. Agricultural Profile of Saskatchewan (data and analytical products: 1996 Census of Agriculture [Cat No 95-179-XPB]). Agriculture Division. Ottawa: Statistics Canada, 1997.

12. Statement of the American Thoracic Society: Standardization of spirometry - 1987 update. Am Rev Respir Dis 1987;136:1285-98.

13. Smith JD. Some biological components of grain and forage dusts. In: Dosman JA, Cockroft DW, eds. Principles of Health and Safety in Agriculture. Boca Raton: CRC Press, 1990;144-6.

14. Hurst TS, Dosman JA. Characterization of health effects of grain dust exposures. Am J Ind Med 1990;17:27-32.

15. Rylander R. Lung diseases caused by organic dusts in the farm environment. Am J Ind Med 1986;10:221-7.

16. Rennie DR, Dosman JA, Senthilselvan A. Prevalence of asthma in a population of Hutterite and non-Hutterite school children. Am J Respir Crit Care Med 1997;155:A251. (Abst)

17. Groth S, Dirksen A, Dirksen H, Rossing N. Intra-individual variation and effect of learning in lung function examinations. A population study. Bull Eur Physiopathol Respir 1986;22:35-42.

18. Jaakkola MS, Ernst P, Jaakkola JJ, N'gan'ga LW, Becklake MR. Effect of cigarette smoking on evolution of ventilatory lung function in young adults: an eight year longitudinal study. Thorax 1991;46:907-13.

19. doPico GA, Flaherty D, Bhansali P, Chavaje N. Grain fever syndrome induced by inhalation of airborne grain dust. J Allergy Clin Immunol 1982;69:435-43.

20. Bharadwaj L, Senthilselvan A, Dosman JA, Gusioski C. Acute changes in lung function in farmers exposed to grain dust. J Agric Saf Health 1999;5:207-14.

21. Schwartz DA, Donham KJ, Olenchock SA, et al. Determinants of longitudinal changes in spirometric function among swine confinement operators and farmers. Am J Respir Crit Care Med 1995; 151:47-53.

22. Kirychuk SP, Senthilselvan A, Dosman JA, et al. Predictors of longitudinal changes in pulmonary function among swine confinement workers. Can Respir J 1998;5:472-8.

23. Senthilselvan A, McDuffie HH, Dosman JA. Association of asthma with use of pesticides: Results of a cross-sectional survey of farmers. Am Rev Respir Dis 1992;146:884-7. 


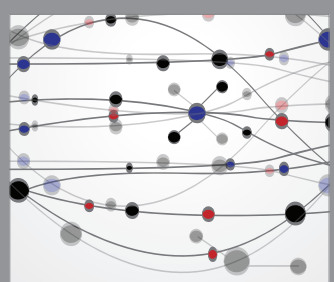

The Scientific World Journal
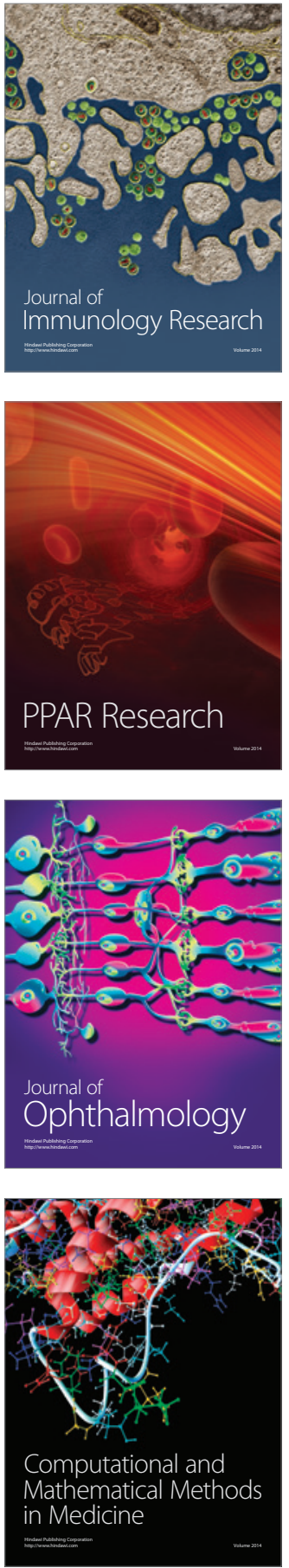

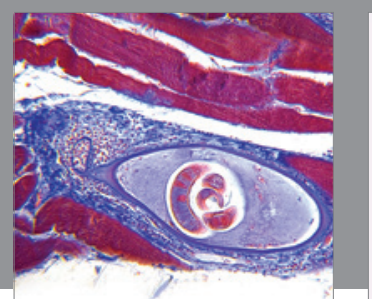

Gastroenterology Research and Practice

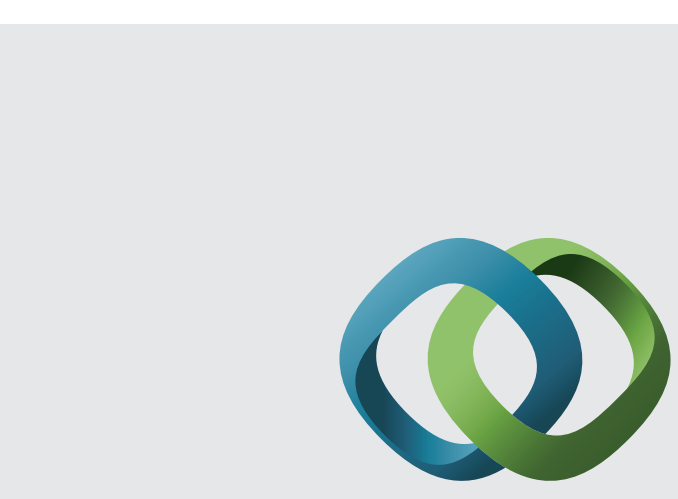

\section{Hindawi}

Submit your manuscripts at

http://www.hindawi.com
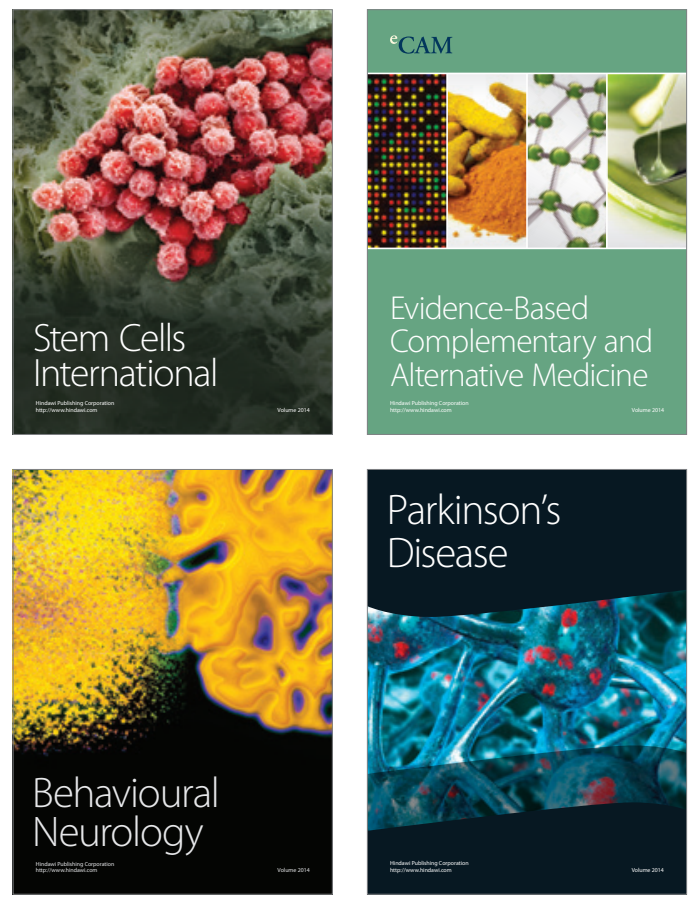
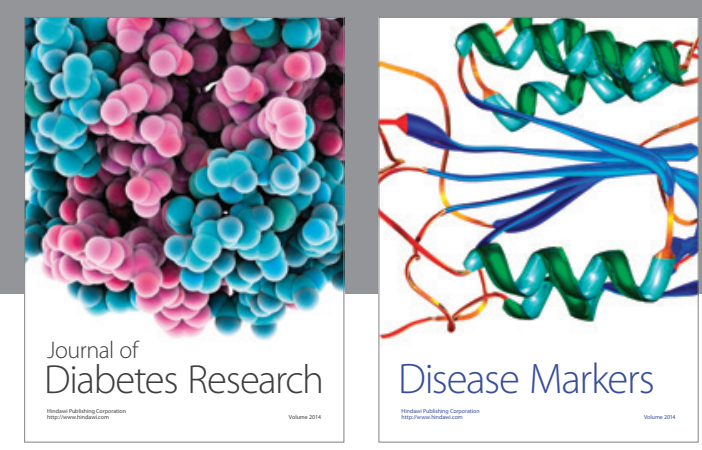

Disease Markers
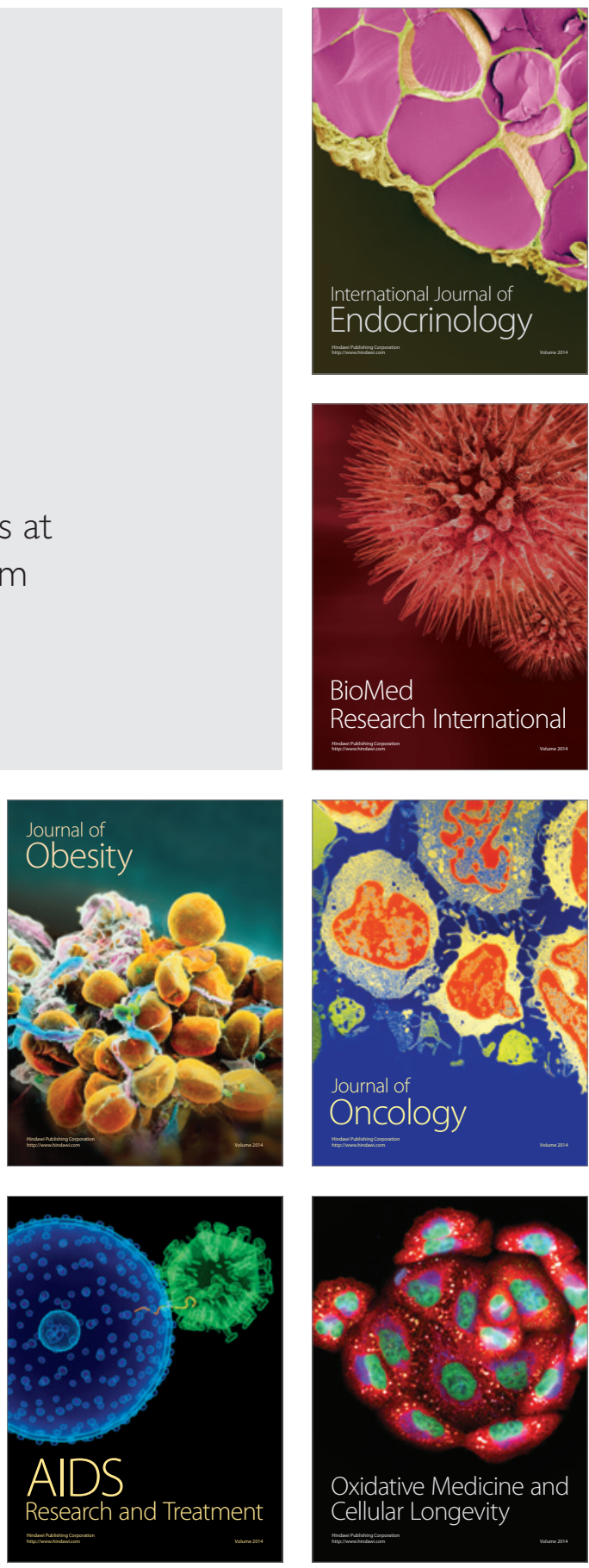